\author{
Improvement Possibilities and Effects of Vegetation Subjected to \\ Long-Term Heavy Grazing in the Steppe Rangelands of Sivas
${ }^{1}$ Central Field Crop Research Institute, Ankara, Turkey
${ }^{2}$ Çankırı Karatekin University, Yapraklı Vocational School, Çankırı, Turkey
${ }^{3}$ Düzce University, Forest Faculty, Düzce, Turkey
${ }^{*}$ Corresponding author (Sorumlu yazar) e-mail: sabahaddin04@yahoo.com

Received (Geliş Tarihi): 02.04.2014 Accepted (Kabul Tarihi): 06.06.2014

\begin{abstract}
Rangelands are actually known as feed resources for animals. At the same time they have potential resources for multiple-uses such as water source, rich of flora and fauna, and recreation areas. They should be carefully used and conserved for their optimum benefits of long term. Deterioration and degradation process have still continued due to mismanagement of rangelands. Present range status should be reversed with good management practices. For this reason, field works were conducted on the rangelands of Sivas Province in years of 2008, 2009 and 2010. A modified wheel point method with loop was used for vegetation survey in the 103 representative study sites of rangelands in Sivas province. The results of this study indicated that vegetation cover was quantified as $60.68 \%$. The cover rates of decreasers and increasers were $15.53 \%$ and $22.23 \%$, respectively. The studied sites numbers were 6,62 , and 35 for good, fair, and poor conditions, respectively. The 97 sites of total sites were identified as fair and poor in condition based on the rangeland condition classes. On the other hand, 26 sites were found at healthy, 35 sites at risky and 42 sites at unhealthy in rangeland health categories. Total site number of the last two classes was 77 . Study results indicate that rangelands are also in slow degradation trend and high potential for having been successively reversed to the climax situation with proper restoration and management practices for rangelands.
\end{abstract}

Keywords: Rangeland condition, health, restoration, management

\title{
Uzun Süre Ağır Otlatmanın Sivas Step Meralarında Vejetasyona Etkileri ve Islah
} İmkânları

\section{Öz}

Meralar gerçekte hayvanlar için yem kaynakları olarak bilinirler. Aynı zamanda meralar, su kaynağı, zengin flora ve fauna olma özelliği ve dinlenme alanı gibi çok yönlü kullanımlar için potansiyel kaynaklara sahiptir. Meralar uzun süreli optimum fayda sağlamak için dikkatli kullanılmalı ve muhafaza edilmelidirler. Bu alanlar hala kötü yönetim nedeniyle bozulmakta ve bu bozulma süreci devam etmektedir. Mevcut mera durumu iyi yönetim uygulamalarıyla tersine çevrilebilir. Bu sebeple Sivas ili meralarında 2008, 2009 ve 2010 yıllarında arazi çalışmaları yürütülmüştür. Vejetasyon etüt çalışmaları lup ile modifiye edilmiş tekerlek nokta yöntemi ile Sivas meralarını temsil eden 103 durakta yapıımıştır. Bu çalışmanın sonucunda bitkiyle kaplı alan \% 60,68 olarak bulunmuştur. Azalıcı ve çoğalıcı bitki türlerinin kaplama oranları sırayla $\% 15,53$ ve $\% 22,23$ ' tür. Incelenen mera duraklarında iyi, orta ve zayıf durumda olan duraklar sırayla 6,62 ve 35 olarak bulunmuştur. Toplam durakların 97 adeti mera durumu orta ve zayıf sınıflamada yer almıştır. Diğer taraftan, mera sağlı̆ı açısından yapılan sınıflamada 26 durak sağlıklı, 35 durak riskli, 42 durak sorunlu olarak bulunmuştur. Toplam 77 adet durak mera sağlığı açısından riskli ve sorunludur. Çalışma sonuçları, meraların yavaş olarak bozulma eğiliminde olduğunu ve bu alanların uygun ıslah ve yönetim uygulamaları ile başarııı olarak orijinal hallerine dönme potansiyeli taşıdığını, göstermiştir.

Anahtar Kelimeler: Mera durumu, sağlığı, yönetimi, ıslahı

Introduction

$R^{a}$

angelands are highly important for environmental aspects and ecosystem.

They are employed with multiple purposes as food, fiber, water resource, recreation function, wildlife (Holechek et al 2004).
Rangeland and relevant factors are monitored for following of change trend over time. Thus present management or use are automatically controlled and reorganized if necessary. The Central Anatolia Region consists 
of 33\% (TÜIK 2001) of total rangeland area which is 14.6 mil. ha (TÜIKK 2012).

The rangelands have been converted to croplands in the result of the rapid development in agricultural mechanization since 1950's. Hence the total area of rangelands has been declined to 14.6 mil ha from approximately 46.4 mil. ha (Tosun 1996).

The balance between livestock and rangelands was changed by increased livestock and declined range production. The rangelands, basic animal feed resources, were misused and overgrazed for long time. As a result unfortunately they lost their quantity and quality (Büyükburç, 1983).

Plant species with perennial palatable and high preference are necessary for rangelands improvement of the Central Anatolia Region. These desired species are required to be expanded on vegetation community for rangeland condition and health.

These following species were detected as dominant plants for region rangelands such as Festuca ovina, Andropogon gryllus, Hedysarum varium, Thymus squarrosus, Artemisia fragrans, Medicago sativa (Bakır 1970; Özmen 1977; Uluocak 1977; Tokluoğlu 1979).

Moreover, some major important species for the rangelands of this region were also encountered such as Poa bulbosa var.vivipara, Bromus erectus, Onobrychis armena, Cynodon dactylon, Stipa lagascae, Teucrium polium, Globularia orientalis (Bakır 1970), and Agrostis sp., Bromus erectus, Stipa pennata, Convolvulus compactus, Noaea spinosissima (Özmen 1977). On the other hand, plant species as Kochia prostate (Tokluoğlu 1979), and Trifolium arvense, T. campestre, T. repens, Onobrychis sativa, $\mathrm{O}$. alba, O. tenuifolia, Koelaria cristata, Agropyron intermedium, A. elongatum, A. trichophorum, Phleum pratense, P. phloides, P. exaratum, Dactylis glomerata, D. hispanica (Uluocak 1977) were specified in the vegetation of rangelands.

Study area description contains botanical composition, climatic data and environmental features (Bakır 1969). After the assessment of current data is identified rangeland condition (excellent, good, fair, poor) and health (healthy, risky and unhealthy) (Bakır 1969; Koç et al. 2003). Moreover, the carrying capacity for rangeland should be also calculated by vegetation biomass or hay yield. Proper management systems should be easily applied for diverse status levels of rangelands with supporting all information given above.
Field study surveys were completed between 2007 and 2011 in the 9 provinces of the Central Anatolia Region. Both provinces, as namely Ankara and Çankırı, were found similar status for range condition and health in a fair and at risky, respectively (Ünal et al. 2012a; Ünal et al. 2012b).

Moreover, the percentage areas of plant cover and bare ground in Ankara and Çankırı were $60.55 \%$ and $39.45 \% ; 65.19 \%$ and $34.81 \%$ at the same study, respectively. These field study results indicated that decreasers and increasers rates in Ankara and Çankırı provinces were measured ranging from $10.24 \%$ to $25.71 \%$ and from $14.72 \%$ to $24.80 \%$, respectively.

These rangelands flora covered the 287 and 327 species in Ankara and Çankırı provinces, respectively. These decreaser species were appeared in both provinces such as Agropyron cristatum, Bromus tomentellus, Dactylis glomerata, Elymus repens, Koeleria cristata, Lotus aegaeus, L. corniculatus, $\mathrm{O}$. armena, $\mathrm{O}$. oxyodonta, Trifolium pratense, and Vicia cracca. These incresears as Cynodon dactylon, Plantago lanceolata, P. bulbosa, Stipa holosericea, and Teucrium polium were also existed in two locations. Other increasers such as Hordeum bulbosum, Poa alpine, Dorycnium pentaphyllum, Ebenus hirsuta, Hedysarum cappadocicum were also seemed. The aim of this study was to determine the condition and the health of rangelands which were relevant plant species cover in vegetation community of the 103 diverse sites. Another objective was to explain the management and improvement practices for various conditions of rangelands in this province.

\section{Material and Method}

Long term annual mean precipitation is 443 $\mathrm{mm}$, precipitation means were $469 \mathrm{~mm}, 577 \mathrm{~mm}$, and $548 \mathrm{~mm}$ in the study years of 2008, 2009 and 2010, respectively (GDSMS, 2010). Long term average temperature is $8.9^{\circ} \mathrm{C}$ but the recorded average temperatures were $8.3^{\circ} \mathrm{C}$, $9.5^{\circ} \mathrm{C}$, and $11.7^{\circ} \mathrm{C}$ in the years of 2008,2009 and 2010 , respectively. The coldest month is January with mean temperature of $-3^{\circ} \mathrm{C}$. The warmest months are July and August with mean temperature of $20^{\circ} \mathrm{C}$. The average relative humidity for long term is about $65.4 \%$, three study year means were lower than that such in 2008, 2009 and 2010, respectively. 


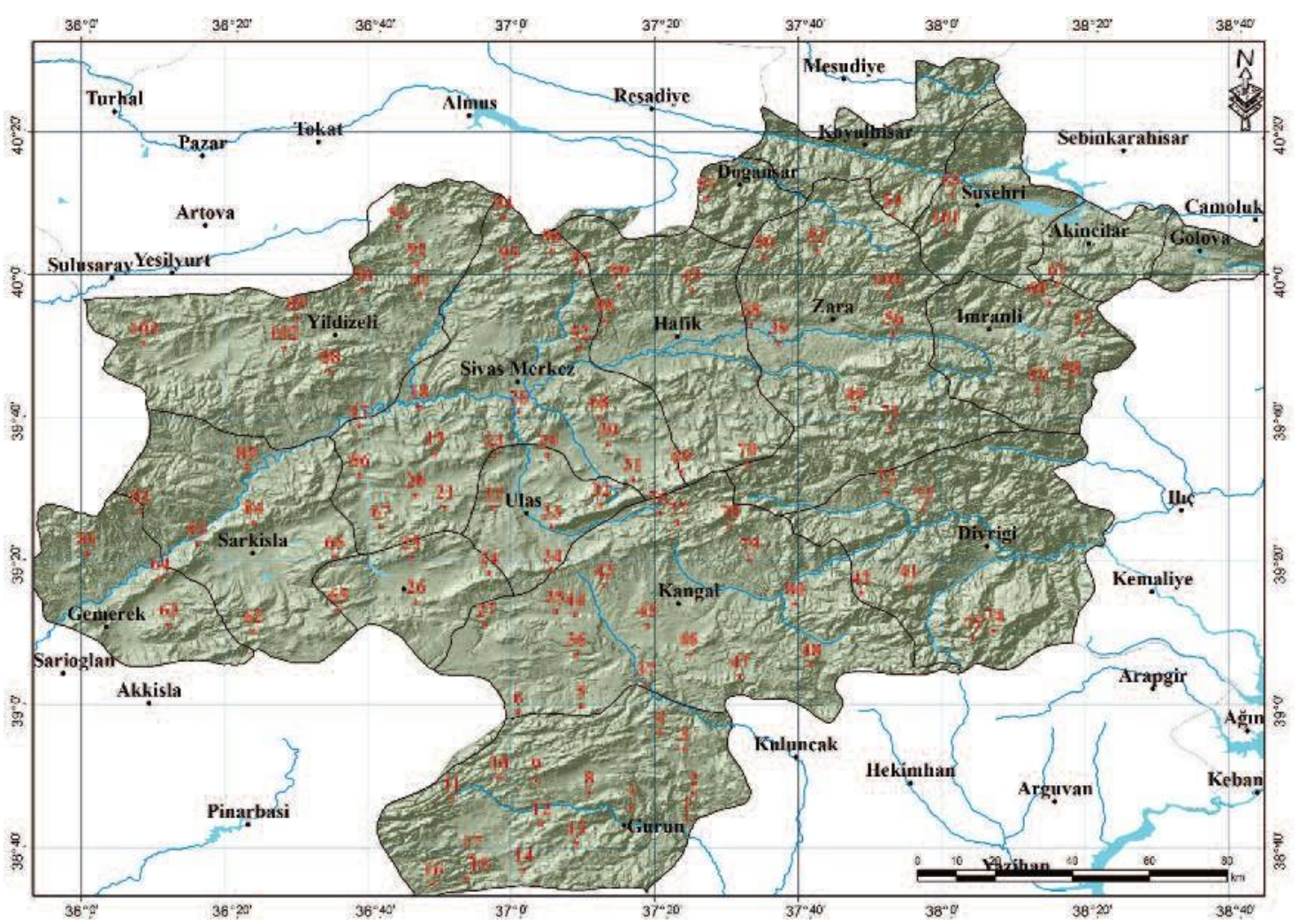

Figure 1. Study sites in the province of Sivas

Şekil 1. Sivas ilindeki çalışma yapılan duraklar

The study area is characterized by steep slopes $(12-19 \%)$ and shallow soils $(20-49 \mathrm{~cm})$. The soil texture class of sites is clay - loam. The soil is neutral $(\mathrm{pH} 7.45)$, high lime content (15.76\%), very low phosphorus amount (2.88 $\mathrm{kg} / \mathrm{da})$, rich potassium content $(95.64 \mathrm{~kg} / \mathrm{da})$, and fair organic matter content (2.04\%) (CSFWRRI, 2010).

The vegetation survey was carried out with a modified wheel point method with loop (Koç and Çakal, 2004) at the representative 103 sites of Sivas province in 2008, 2009, and 2010 (Figure 1).

Two transect lines having a $100 \mathrm{~m}$ long were performed at each site. The 200 reading points including $0.50 \mathrm{~m}$ intervals were written down along transects. Plant samples were carefully picked up and dried up for making herbarium. They all were specified according to flora books of Davis (1965-1985 and 1988) and Güner et al (2000).

Moreover, site habitat factors (altitude, aspect, slope, and distance to village) and effects of rangeland management (grazing intensity, erosion, and soil compactness) were written down.
The cover percentages of plant species, bare ground area and stoniness on rangeland vegetation were measured during field work. The rangeland condition (only cover of decreasers and increasers used) were categorized as excellent, good, fair, poor and health (vegetation cover ) were also classified as healthy, at risky, and unhealthy based on the basal cover of rangeland vegetation (Koç et al. 2003).

Rangeland and meadow area is 1207916 ha. The total livestock numbers are 258.360, 207.510, and 268.372 Animal Unit (AU) in 2008, 2009 and 2010, respectively (PAED, 2010). Carrying capacity (CC) of total rangeland and meadow area in Sivas province is $214.741 \mathrm{AU}$. Livestock numbers are much more $20.3 \%$, $3.4 \%$, and $24.9 \%$ in 2008, 2009, and 2010 than $\mathrm{CC}$ of Sivas rangelands. Annual hay requirement of livestock of the province is 1.178 .768 tons, but rangeland and meadow production capacity are only 483.166 tons ( $40.9 \%$ of total requirement).

\section{Results and Discussions}

\section{General assessment}

The rangeland condition of Sivas province was identified and categorized into "fair" class (having the total values of decreasers and 
increasers as $37.76 \%$ ) based on plant species (Table 1). In the same table, the proportions of decreaser, increaser and invader species in vegetation cover were $15.53 \%, 22.23 \%$ and $62.54 \%$, respectively.

The Province rangeland health was found in a risky categorize having the percentages of botanical composition and bare ground as $60.68 \%$ and $39.32 \%$, respectively (Table. 1).

Ankara and Çankırı provinces in the Central Anatolian Region had the same status for range condition and health, in a fair and at risky, respectively (Ünal et al. 2012a; Ünal et al. 2012b). Over - grazing may naturally cause unfavorable range status.

\section{Rangeland health}

Rangeland health values of the study sites were given in Table 2. The plant coverage area and bare ground were found as $80.90 \%$ and $19.10 \%$; $62.15 \%$ and $37.85 \%$; $46.94 \%$ and $53.06 \%$ at healthy (26 sites), risky (35 sites), and unhealthy (42 sites) respectively (Table 2). In the same table, the 77 sites of total 103 sites were the worst health classes at risky and unhealthy.

In both provinces of Ankara and Çankırı, the percentages of vegetation cover and bare ground were found to be as $77.75 \%$ and $22.25 \% ; 79.04 \%$ and $20.96 \% ; 63.77 \%$ and $36.23 \% ; 64.52 \%$ and $35.48 \% ; 49.30 \%$ and $50.70 \% ; 46.23 \%$ and $53.77 \%$ at healthy, risky, and unhealthy of the health classes, respectively (Ünal et al. 2012a; Ünal et al. 2012b).

These data showed that three provinces rangelands (Ankara, Çankırı and Sivas) a have similar declining trend on range health. It refers that rangeland health and management look like to each other in the regional provinces.

Healthy rangeland class in Table 2 had the highest vegetation cover with $99.75 \%$. The lowest and the highest values of vegetation cover rates in the same consecutive classes for

Table 1. The values of vegetation cover and bare ground on rangeland (\%)

Çizelge 1. Meradaki bitkiyle kaplı alan ve çıplak alan değerleri (\%)

\begin{tabular}{|c|c|c|c|c|c|c|c|c|}
\hline & & VC & $B G$ & D & IC & IV & ICURC & SURC \\
\hline Mini & & 35.50 & 0.25 & 1.38 & 0.63 & 18.44 & 0.63 & 6.29 \\
\hline $\operatorname{Max}$ & & 99.75 & 64.50 & 46.48 & 67.72 & 93.71 & 33.86 & 66.48 \\
\hline Ave & & 60.68 & 39.32 & 15.53 & 22.23 & 62.54 & 16.33 & 31.56 \\
\hline Stan & error & 14.92 & 14.92 & 9.70 & 13.55 & 16.23 & 6.44 & 11.95 \\
\hline Coe & variation $(\%)$ & 24.58 & 37.94 & 62.47 & 60.94 & 25.95 & 39.45 & 37.85 \\
\hline Expla & & & & & & & & \\
\hline VC & $\begin{array}{l}\text { Vegetation cover } \\
\text { Bitkiyle kapl } \text { alan }\end{array}$ & & IV & $\begin{array}{l}\text { Invade } \\
\text { «stilac }\end{array}$ & & & & \\
\hline$B G$ & $\begin{array}{l}\text { Bare ground } \\
\text { Çıplak alan }\end{array}$ & & IURC & $\begin{array}{l}\text { Increa } \\
\text { Mera }\end{array}$ & $\begin{array}{l}\text { Used } \\
\text { Imunun }\end{array}$ & $\begin{array}{l}\text { Range } \\
\text { pitinde }\end{array}$ & $\begin{array}{l}\text { Idition } \\
\text { anslan çc }\end{array}$ & |>c> türler \\
\hline D & $\begin{array}{l}\text { Decreasers } \\
\text { Azalıcılar }\end{array}$ & & SURC & $\begin{array}{l}\text { Specie } \\
\text { Mera }\end{array}$ & $\begin{array}{l}\text { sed for } \\
\text { Imunun }\end{array}$ & $\begin{array}{l}\text { fge Co } \\
\text { pitinde }\end{array}$ & $\begin{array}{l}\text { ion } \\
\text { an>lan bi }\end{array}$ & türleri \\
\hline IC & $\begin{array}{l}\text { Increasers } \\
\text { Çoi)al }>c \text { c/ar }\end{array}$ & & & & & & & \\
\hline
\end{tabular}

Table 2. Vegetation cover, bare ground and rangeland health values Çizelge 2. Bitkiyle kaplı alan, çıplak alan ve mera sağlık değerleri

\begin{tabular}{|c|c|c|c|c|}
\hline $\begin{array}{l}\text { Health values or } \\
\text { health classes }\end{array}$ & $\begin{array}{l}\text { Site } \\
\text { numbers }\end{array}$ & Descriptive statistics & $\begin{array}{l}\text { Vegetation } \\
\text { cover (\%) }\end{array}$ & $\begin{array}{c}\text { Bare ground } \\
(\%)\end{array}$ \\
\hline \multirow{5}{*}{ Healthy } & \multirow{5}{*}{26} & Minimum & 71.25 & 0.25 \\
\hline & & Maximum & 99.75 & 28.75 \\
\hline & & Average & 80.90 & 19.10 \\
\hline & & Standard error & 9.78 & 9.78 \\
\hline & & Coefficient variations (\%) & 12.09 & 51.20 \\
\hline \multirow{5}{*}{ Risky } & \multirow{5}{*}{35} & Minimum & 56.25 & 30.25 \\
\hline & & Maximum & 69.75 & 43.75 \\
\hline & & Average & 62.15 & 37.85 \\
\hline & & Standard error & 4.08 & 4.08 \\
\hline & & Coefficient variations (\%) & 6.56 & 10.78 \\
\hline \multirow{5}{*}{ Unhealthy } & \multirow{5}{*}{42} & Minimum & 35.50 & 44.25 \\
\hline & & Maximum & 55.75 & 64.50 \\
\hline & & Average & 46.94 & 53.06 \\
\hline & & Standard error & 5.55 & 5.55 \\
\hline & & Coefficient variations (\%) & 11.83 & 10.47 \\
\hline
\end{tabular}


these three health classes were determined as $71.25 \%, 99.75 \% ; 56.25 \%, 69.75 \%$ and $35.50 \%$, $55.75 \%$, respectively. Consequently, regional rangelands have been misused such as early, late, and heavy grazing, so they appear in unfavorable trend.

\section{Rangeland condition}

The condition data of survey sites is presented in Table 3. Three different classes of rangeland conditions were found as good (6 sites), fair (62 sites), and poor (35 sites) in the province of Sivas.

The total number of fair and poor sites of conditions was 97 (Table 3). These data are early an indicator for slow degradation process of rangelands. But, it isn't sustainable for conservation and improvement of current status in the future.

The only 6 sites of the 103 sites were in a good rangeland condition and its decreasers cover was found as $34.96 \%$ in botanical composition, but it had the percentages of $33.35 \%$ and $31.68 \%$ of increaser and invader species, respectively. Proper management techniques should be exerted for these sites to benefit at optimum level and to conserve its present status.

The cover rates of decreasers and increasers in Ankara and Çankırı good rangeland conditions were quantified as $43.09 \%$ and $32.87 \% ; 49.36 \%$ and $13.33 \%$, respectively (Ünal et al. 2012a; Ünal et al. 2012b).
The 62 sites of total 103 survey sites were in a fair class containing the percentages of decreasers and increasers in botanical composition of $17.92 \%$ and $25.83 \%$, respectively (Table 3 ). When decreaser and increaser species rates lowered; on the contrary, invader species cover area enlarged on vegetation community.

Invader species also led to increase and dramatically reached to $56.53 \%$. The cover rates of decreasers and increasers in Ankara and Çankırı fair rangeland conditions were quantified as $15.13 \%$ and $28.91 \% ; 15.19 \%$ and $25.33 \%$, respectively (Ünal et al. $2012 a$; Ünal et al. 2012b). In the fair condition, grazing impacts and habitat factors together cause spatial and temporal variation on vegetation community composition in long-term.

The 35 sites in a poor class of rangeland condition have the percentage of decreasers and increasers on botanical composition of $7.81 \%$ and $13.93 \%$, respectively (Table 3 ). In the poor class, both decreasers and increasers rates in the community of vegetation were the lowest to other classes' data.

Invaders rate in the poor categorize was $78.49 \%$ which was the highest rate in the all three classes. In the poor sites, it is easily seen above percentage data, grazing intensity plays important role on plant cover and vegetation community composition.

The cover rates of decreasers and increasers in Ankara and Çankırı poor range

Table 3. Rangeland conditions of sites and the percentages (\%) of decreasers, increasers and invaders on botanical composition

Çizelge 3. Durakların mera durumları ve bitkiyle kaplı alan içerisindeki azalıcı, çoğalıcı ve istilacı türlerin oranları (\%)

\begin{tabular}{|c|c|c|c|c|c|c|c|}
\hline $\begin{array}{l}\text { Rangeland } \\
\text { condition }\end{array}$ & $\begin{array}{l}\text { Site } \\
\text { numbers }\end{array}$ & Descriptive statistics & $D^{*}$ & IC & IV & IURC & SURC \\
\hline \multirow{5}{*}{ Good } & \multirow{5}{*}{6} & Minimum & 23.75 & 23.80 & 18.44 & 20.00 & 51.33 \\
\hline & & Maximum & 46.48 & 57.81 & 44.88 & 28.91 & 66.48 \\
\hline & & Average & 34.96 & 33.35 & 31.68 & 21.48 & 56.45 \\
\hline & & Standart error & 7.50 & 12.56 & 10.39 & 3.64 & 5.44 \\
\hline & & Coefficient variations (\%) & 21.46 & 37.67 & 32.78 & 16.92 & 9.64 \\
\hline \multirow{5}{*}{ Fair } & \multirow{5}{*}{62} & Minimum & 6.01 & 6.63 & 30.43 & 6.63 & 26.01 \\
\hline & & Maximum & 37.68 & 67.72 & 72.10 & 33.86 & 50.73 \\
\hline & & Average & 17.92 & 25.83 & 56.53 & 18.63 & 36.27 \\
\hline & & Standart error & 7.98 & 12.58 & 10.50 & 4.59 & 6.72 \\
\hline & & Coefficient variations (\%) & 44.52 & 48.69 & 18.58 & 24.66 & 18.53 \\
\hline \multirow{5}{*}{ Poor } & \multirow{5}{*}{35} & Minimum & 1.38 & 0.63 & 53.85 & 0.63 & 6.29 \\
\hline & & Maximum & 18.54 & 46.15 & 93.71 & 23.08 & 25.50 \\
\hline & & Average & 7.81 & 13.93 & 78.49 & 11.38 & 18.96 \\
\hline & & Standart error & 4.49 & 11.27 & 8.99 & 6.72 & 5.46 \\
\hline & & Coefficient variations (\%) & 57.53 & 80.87 & 11.45 & 59.05 & 28.77 \\
\hline
\end{tabular}

* Explanation was given in Table 1. 
conditions were measured as $4.21 \%$ and $22.66 \% ; 3.13 \%$ and $27.13 \%$, respectively (Ünal et al. 2012a; Ünal et al. 2012b). Decreasers cover value of poor condition in Sivas province was higher than those values in other provinces, but increasers data was too lower than Ankara and Çankırı's. In the poor sites, grazing intensity reaches at highest level on plant species especially containing good quality species (called as decreasers and increasers) but these desired plant species remarkably exist on vegetation community of rangelands.

\section{Plant species}

The floristic composition of vegetation has 422 species that refer to an indicator for a wide range diversity of plant species. Ankara, Çankırı and Kayseri provinces comprised the 287, 327 and 263 species in their rangeland vegetation, respectively (Ünal et al. 2012a; Ünal et al. 2012b; Ünal et al. 2013). These data mean that high species richness appears in regional range vegetation community composition.

The decreasers (32 species), increasers (34 species) and some invaders (356 species) on botanical composition were presented in Table 4 and Table 5.

Table 4. Decreaser (32) and increaser (34) plant species on the rangeland vegetation Çizelge 4. Mera vejetasyonu içerisindeki azalıcı (32) ve çoğalıcı (34) bitki türleri

\begin{tabular}{l} 
Decreasers \\
\hline Agrostis canina \\
Agrostis stolonifera \\
Alopecurus arundinaceus \\
Bromus inermis \\
B. tomentellus \\
B. variegatus \\
Dactylis glomerata \\
Elymus lazicus \\
E. hispidus E. \\
repens Koeleria \\
cristata Lolium \\
perenne \\
Phleum montanum \\
Poa angustifolia \\
P. densa \\
P. pratensis
\end{tabular}

Legumes

$\frac{\text { Increasers }}{\text { Grasses }}$

Brachypodium pinnatum

Bromus cappadocicus

Bromus riparius

Cynodon dactylon

Festuca callieri

Festuca valesiaca

Hordeum bulbosum

Hordeum violaceum

Phleum bertolonii

Plantago lanceolata

Poa alpina

Poa bulbosa Poa

trivialis Sesleria

phleoides

Stipa ehrenbergiana

Stipa holosericea

Stipa lessingiana

Trisetum turcicum

Lotus corniculatus

Medicago falcata

M. sativa

M. varia

Onobrychis albiflora

O. armena

O.hypargyrea

O. oxyodonta

O. paucijuga

O. stenostachya

Trifolium ambiguum

T. pannonicum

T. pratense

T. repens

Vicia cracca

Other
Anthyllis vulneraria

Coronilla orientalis

Coronilla varia

Dorycnium graecum

Dorycnium pentaphyllum

Ebenus laguroides

Hedysarum candidissimum

Hedysarum pestalozzae

Hedysarum pycnostachyum

Hedysarum varium

Lathyrus czeczottianus

Sanguisorba minör

Dianthus floribundus

Juncus gerardi

Teucrium polium 
Table 5. Invader plant species on the rangeland vegetation (82)-356

Çizelge 5. Mera vejetasyonu içerisindeki istilacı bitki türleri (82)-356

\begin{tabular}{lll}
\hline Acantholimon acerosum & Daphne oleoides & Salvia caespitosa \\
Achillea biebersteinii & Dianthus anatolicus & Salvia cryptantha \\
Aegilops speltoides & Dianthus orientalis & Salvia vermifolia \\
Agrostis intermedia & Ebenus macrophylla & Salvia wiedemannii \\
Ajuga salicifolia & Eryngium campestre & Sedum album \\
Alyssum desertorum & Euphorbia macroclada & Sesleria alba \\
Alyssum murale & Galium incanum & Sideritis montana \\
Alyssum pateri & Galium verum & Silene caryophylloides \\
Androsace maxima & Genista albida & Taeniatherum caput-medusae \\
Artemisia santonicum & Genista sessilifolia & Tanacetum cadmeum \\
Astragalus angustifolius & Gypsophila eriocalyx & Tanacetum nitens \\
Astragalus lineatus & Gypsophila parva & Taraxacum crepidiforme \\
Astragalus plumosus & Helianthemum ledifolium & Teucrium chamaedrys \\
Astragalus wiedemannianus & Helianthemum nummularium & Teucrium parviflorum \\
Bromus japonicus & Herniaria incana & Thymus sipyleus \\
Bromus lanceolatus & Marrubium parviflorum & Trachynia distachya \\
Bromus sterilis & Minuartia hamata & Tragopogon dubius \\
Bromus tectorum & Minuartia hybrida & Trifolium arvense \\
Carduus nutans & Ononis spinosa & Trigonella fischeriana \\
Carex flacca & Onosma taurica & Trigonella monantha \\
Centaurea carduiformis & Paronychia argyroloba & Tripleurospermum tenuifolium \\
Centaurea urvillei & Paronychia kurdica & Veronica multifida \\
Centaurea virgata & Phleum exaratum & Xeranthemum annuum \\
Convolvulus holosericeus & Phlomis angustissima & Ziziphora clinopodioides \\
Convolvulus lineatus & Polygala anatolica & Ziziphora taurica \\
Crepis foetida & Potentilla recta & Ziziphora tenuior \\
Crepis sancta & Ranunculus arvensis & \\
Cruciata taurica & Reseda lutea & \\
\hline & & \\
\hline
\end{tabular}

In this work, important decreaser grasses Tokluoğlu 1979) and Festuca ovina $=\mathrm{F}$. contained following species: Agrostis valesiaca, F.callieri (Bakır 1970; Özmen 1977; stolonifera, Bromus tomentellus, Elymus Uluocak 1977; Ünal et al. 2010; Ünal et al. hispidus, Koeleria cristata, Phleum montanum 2011; Ünal et al. 2013).

and Poa pratensis.

Following decreasers were encountered in Ankara and Çankırı provinces such as Agropyron cristatum, Bromus tomentellus, Dactylis glomerata, Elymus repens, Koeleria cristata, Lotus aegaeus, L. corniculatus, Onobrychis armena, O. oxyodonta, Trifolium pratense, and Vicia cracca. (Ünal et al. 2012a; Ünal et al. 2012b; Ünal et al. 2013).

Increaser grasses were also detected Cynodon dactylon, Festuca callieri, F. valesiaca, Hordeum bulbosum, Poa alpina, P. bulbosa, P. trivialis and Stipa holosericea.

The following plant species became in the previous studies through The Central Anatolian Region: Andropogon gryllus, (Bakır 1970;
Dominant plant species of this region such as Poa bulbosa var. vivipara, Cynodon dactylon (Bakır 1970; Ünal et al. 2013), Koelaria cristata, Agropyron intermedium, A. elongatum, A. trichophorum were also detected in the previous field work and this survey.

Some decreaser legume species such as Medicago sativa, Onobrychis albiflora, $\mathrm{O}$. oxyodonta, Trifolium ambiguum, and $\mathrm{T}$. pratense were identified in the field work.

Some increaser forage legumes such as Coronilla orientalis, C. varia, Dorycinium pentaphyllum, Hedysarum pestalozzae and Hedysarum varium were also found. 
The similar species as Hedysarum varium were come across in the past surveys and this study (Bakır 1970; Tokluoğlu 1979), Medicago sativa (Bakır 1970; Uluocak 1977; Ünal et al. 2013), Onobrychis armena (Bakır 1970; Ünal et al. 2010; Ünal et al. 2013) and Onobrychis sativa, O. alba, O. tenuifolia (Uluocak 1977) that are exactly important to be improved and over-seeded for regional rangeland vegetation.

These incresears as Cynodon dactylon, Plantago lanceolata, P. bulbosa, Stipa holosericea and Teucrium polium also were come across in Ankara and Çankırı provinces (Ünal et al. 2012a; Ünal et al. 2012b). Other increasers such as Hordeum bulbosum, Poa alpine, Dorycnium pentaphyllum, Ebenus hirsuta, Hedysarum cappadocicum also appeared in vegetation of Ankara province (Ünal et al. 2012a).

Some invader species in the study area were Alyssum desertorum, A. murale, Artemisia santonicum, Taeniatherum caputmedusae, Eryngium campestre, Euphorbia macroclada, Phlomis angustissima, Potentilla recta, Salvia cryptantha, Teucrium chamaedrys, Thymus sipyleus and Ziziphora taurica.

Dominant species at the steppe vegetation existed as Thymus squarrosus (Bakır 1970; Özmen 1977; Tokluoğlu 1979; Ünal et al. 2010; Ünal et al. 2011), Artemisia fragrans (Özmen 1977; Tokluoğlu, 1979; Ünal et al. 2010; Ünal et al. 2011) which have synonyms with Artemisia santonicum and Thymus sipyleus occurring in this work.

\section{Conclusions}

Range condition and health classes were found as fair and risky. The rangelands of Sivas province were in a good condition at 6 sites, fair condition at 62 sites, and poor condition at 35 sites.

The status of total 97 sites, consisting of fair and poor sites, may be also accepted as an indicator of misused in the past of rangeland management.

As a result, rangelands have been mismanaged having early, late, and over grazing in a long term.

There appears three various range conditions in this work, so management and rehabilitation practices should be immediately applied as given follows:

For good condition class, current status should be maintained with optimum benefit level and supported having fertilization and grazing system. Recommended fertilization rates are as $50 \mathrm{~kg}$ of nitrogen and phosphorous per hectare for yield and quality of rangeland vegetation (Büyükburç 1999). Range management is especially based upon grazing period and carrying capacity.

For fair condition category, this status is critical situation towards degradation and restoration of rangelands, for this reason management and improvement techniques may be finely found and carefully applied for its rehabilitation. Rangeland management based on grazing period and carrying capacity is vital important. At the same time, improvement methods such as fertilization $(50 \mathrm{~kg} \mathrm{~N}+50 \mathrm{~kg}$ P2O5 per ha) (Büyükburç 1999), over-seeding and weed control should be applied together. Moreover, it is a big chance having a herbage production of forage crops for both rangeland improvement and livestock needs.

For poor condition class, all rehabilitation activities should be well designed. First, rangelands in this class must not be grazed for three year period. Second, over-seeding and weed control should be implemented together and correctly managed during this period. Third, plant cover should be expanded and the rate of palatable species on vegetation community should be also increased with sustainable management and rehabilitation strategies on these range sites.

Consequently, spatial and temporal changes on range vegetation should be monitored over time for new implements and improvements in the future.

\section{Acknowledgments}

This work was concluded in framework of National Rangeland Management and Use Project. It was supported by The Scientific and Technological Research Council of Turkey (TÜBITAK- (KAMAG Project No: 106G017), General Directories of Plant Production and Food and Control of Republic of Turkey Ministry of Food, Agriculture and Livestock. I would like to thank Dr. Ali Mermer and Dr. Ediz Ünal for their helps, concepts, and supports on paper preparation. 


\section{Literature}

Bakır Ö. 1969. Studies on the ecological factors affecting growth and improvement of major forage crops. Ankara University, Agricultural Faculty Press, 327. Ankara.

Bakır Ö. 1970. A rangeland vegetation survey in the field of Middle-East Technical University. Ankara University, Agricultural Faculty Press, 382. Ankara.

Büyükburç, U. 1983. A study of rangeland improvement with fertilization and resting on the rangeland of Yavrucak village of Ankara Provence. Rangeland Meadow and Livestock Research Institute, Press No.79, Ankara.

Büyükburç U. 1999. A research on improvement possibilities and grazing system of rangelands ( local name, Dereağzı) in Çamlıbel Town of Tokat Province. Turkey 3rd Field Crops Congress, 15-18 November, 1999, Adana, vol.3:1-5.

CSFWRRI 2010. Soil analysis results of studied sites of Sivas province. Central Soil, Fertilizer and Water Resources Research Institute, Ankara.

Davis P.H. (ed.). 1965 - 1985. Flora of Turkey and the East Aegean Islands, Vol. 1 - 9, Edinburgh Univ. Press., Edinburgh.

Davis P.H., Mill R.R., and Tan K., 1988. Flora of Turkey and the East Aegean Islands, Edinburgh Univ. Press., (supple. 1), Vol. 10, Edinburgh Univ. Press, Edinburgh.

GDSMS 2010. The climatic data of Sivas province. The General Director of State Meteorological Service, Ankara, Turkey.

Güner A., Özhatay N., Ekim T., and Başer K.H.C., 2000. Flora of Turkey and the East Aegean Islands, (supple. 2), Vol. 11, Edinburgh Univ. Press., Edinburgh.

Holechek J.L, Pieper R.D., and Herbel C. H., 2004. Rangeland and Man. Range Management, Principles and Practices, pp. 1-28.

Koç A., Gökkuş A. and Altın M., 2003. Comparison of commonly used determination methods of rangeland condition in the world and a suggestion for Turkey. Turkey V. Field Crops Congress, 13-17 October, Diyarbakır, p. 36-42.

Koç A. and Çakal Ş., 2004. Comparison of some rangeland canopy coverage methods. Int. Soil Cong. On Natural Resource Manage. For Sust. Develp., June 7-10, Erzurum, Turkey, D7, 41-45.

Özmen T., 1977. The trials on the vegetation of the rangeland in Konya Province PHD thesis (not printed), Rangeland -Meadow and Livestock Research Institute, Ankara.
PAED 2010. Agricultural data of Sivas Province. The provincial agriculture extension directorates of Sivas.

Tokluoğlu M., 1979. Studies on morphological, biological and agronomical important characters of some rangeland plants. Ankara University, Agricultural Faculty Press No: 728, Ankara.

Tosun F., 1996. History, present and future of Rangeland -meadow and forage crops in the herbage production of Turkey. Turkey 3rd Rangeland Meadow and Forage Crops Congress, 17-19 June, Erzurum p.1-15.

TÜIK 2001. Agriculture census, Turkish Statistical Institute.

TÜIK 2012. Agriculture - Crop production statistics, Turkish Statistical Institute.

Uluocak N., 1977. Rangelands and rangelands in forest. The Ministry of Food- Agricultural and Livestock, The General Directorate of The Agricultural Affairs, No, 6.

Ünal S., Dedebali M. and Ocal M. B., 2010. Ecological interpretations of rangeland condition of some villages in Kirikkale Province of Turkey. Turkish Journal of Field Crops Volume:15, No:1, 43-49.

Ünal S., Karabudak E., Öcal, M.B. and Koç A., 2011. Interpretations of vegetation changes of some villages rangelands in Çankiri Province of Turkey. Turkish Journal of Field Crops, 16(1): 39-47.

Ünal S., Mutlu Z., Mermer A., Öztekin U., Ünal E, Aydoğdu M., Dedeoğlu F., Özaydın K. A., Avağ A., Aydoğmuş O., Şahin B. and Aslan S., 2012a. A Study on assessment of rangelands in Ankara Province. Journal of Field Crops Central Research Institute 2 (21): 41-49.

Ünal S., Mutlu Z., Mermer A., Öztekin U., Ünal E., Özaydın A., Avağ A., Yıldız H., Aydoğmuş O., Şahin B. and Aslan S., 2012b. A study on determination of condition and health of rangelands in Çankırı Province. TabadResearch Journal of Agricultural Sciences 5(2):131-135 (Prof Dr. Selahattin İptaş Agricultural Congress).

Ünal S., Mutlu Z., Öztekin U., Hakan Y. and Şahin B., 2013. Evaluation and determination of rangeland vegetation in Kayseri Province. Journal of Field Crops Central Research Institute 22 (2): 86-95. 
